Chirurgia (2018) 113: 765-771

No. 6, November-December

Copyright $\odot$ Celsius

http://dx.doi.org/10.21614/chirurgia.113.6.765

\title{
Large Paraesophageal Hiatus Hernia: Is Surgery Mandatory?
}

\author{
Dionysios Dellaportas, Ioannis Papaconstantinou, Constantinos Nastos, Georgios Karamanolis, \\ Theodosios Theodosopoulos
}

$2^{\text {nd }}$ Department of Surgery, Aretaieion University Hospital, Medical School of Athens, Greece

Corresponding author:

Dionysios Dellaportas, MD, PhD, FEBS ECS)

$2^{\text {nd }}$ Department of Surgery, Aretaieion University Hospital, Medical School of Athens Greece

E-mail: dellapdio@gmail.com

\section{Rezumat}

Herniile paraesofagiene voluminoase: este tratamentul chirurgical obligatoriu?

Introducere: Deşi herniile hiatale paraesofagiene sunt relativ rar întâlnite, incidența lor se înscrie pe o traiectorie ascendentă, în momentul de față ele reprezentând c. 5-10\% din numărul total de hernii hiatale. Scopul acestui review al literaturii este de a prezenta controversele legate de tabloul clinic şi de investigațiile esențiale preoperatorii, cât şi de a reliefa opțiunile chirurgicale sau nonchirurgicale de tratament.

Material şi Metodă: Toate articolele continând cuvintele cheie 'hernie paraesofagiană voluminoasă sau gigantă', 'hernie hiatală/de hiatus', 'chirurgie laparoscopică', 'chirurgie antireflux', 'plasă', 'volvulus gastric' şi 'hernie diafragmatică' publicate între 1998 şi 2017 în platforma PubMed au fost luate în considerare pentru a fi incluse în studiu.

Rezultate: Simptomatologia acestei afecțiuni este nespecifică şi poate fi atribuită în mod eronat unui număr semnificativ de alte patologii. În cursul evoluției pot surveni complicații semnificative, cum ar fi volvulusul gastric şi necroza gastrică, care, în contextul prezentării nespecifice, pot crea un tablou clinic confuz. Optiunile terapeutice în context electiv sunt controversate, tratamentul chirurgical fiind dificil de justificat în ceea ce priveşte o prezentare cu simptomatologie minimă, în special la pacienți vârstnici şi cu eventuale multiple comorbidități. $\mathrm{Cu}$ toate acestea, în era chirurgiei laparoscopice perihiatale, reducerea stresului operator conferă abordării chirurgicale un avantaj semnificativ în contextul operațiilor elective. În ceea ce priveşte aspectele de tehnică 
chirurgicale (adaugarea unei proceduri antireflux sau nu, oportunitatea gastropexiei, utilizarea unei plase prostetice pentru ranforsarea hiatusului esofagian) cât şi relevanța clinică a recurenței documentate endoscopic sau radiologic, nu există în prezent un consens, aceste probleme aflându-se încă în dezbatere.

Concluzii: Tratamentul laparoscopic al herniilor hiatale paraesofagiene este eficient, şi este asociat cu o rată de morbiditate scăzută în cazul în care este oferit fie pacienților simptomatici, fie celor asimptomatici dar cu un risc perioperator satisfăcător. Sunt necesare studii suplimentare pentru a evalua diferitele inovații legate de tehnica operatorie (ex. utilizarea plasei prostetice sau gastropexia), cât şi pentru a îmbunătăți înțelegerea complicațiilor postoperatorii şi a riscului de recurentă postoperatorie.

Cuvinte cheie: hernie hiatală paraesofagiană, cura laparoscopică a herniei hiatale, volvulus gastric, stomac intratoracic

\begin{abstract}
Purpose/Aim: Paraesophageal hiatus hernias are seldom found, however the incidence is increasing accounting for $5-10 \%$ of all hiatal hernias. The aim of this review is to emphasize controversies in clinical presentation, essential workup investigations and highlight non-surgical and surgical management options.

Materials and Methods: A PubMed literature search using the keywords 'large or giant paraesophageal hernia', 'hiatus or hiatal hernia', 'laparoscopic surgery', 'antireflux surgery', 'mesh', 'gastric volvulus' and 'diaphragmatic hernia' published between 1998 until 2017 was conducted.

Results: Presenting symptoms are non-specific and can be erroneously attributed to various more common medical conditions. Significant complications as gastric volvulus and stomach necrosis, may occur and the obscured clinical presentation can be confusing for the clinician. Management options in the elective setting are controversial, and surgical repair cannot be easily justified for a minimally symptomatic condition, especially in an elderly and perhaps frail patient. However, in the era of laparoscopic surgery around the hiatus, reduced operative stress makes surgical repair appealing in the elective setting. Surgical matters as the adjunct of an antireflux procedure or not, the use of prosthetic mesh to reinforce the hiatus, gastropexy and the clinical importance of radiological or endoscopic recurrence are still under debate.

Conclusions: The laparoscopic treatment of paraesophageal hiatus hernias is effective with low morbidity rates, offered in symptomatic patients and good operative risk asymptomatic individuals. More studies are needed to assess improvement suggestions, as the use of prosthetic mesh or gastropexy, regarding complications and recurrence risks.
\end{abstract}

Key words: paraesophageal, hiatus hernia, laparoscopic hiatus hernia repair, gastric volvulus, intrathoracic stomach

\section{Introduction}

Large paraoesophageal hiatus hernias $(\mathrm{HH})$ occur mostly in the elderly, after the age of 70 (1). Its incidence is about $5-10 \%$ of all $\mathrm{HHs}$, however it is increasing in observational studies, due to the ageing population. Minor problems, as anemia, up to life-threatening complications, as gastric volvulus and necrosis of the stomach, may potentially arise in these patients and management can be troublesome (2). Clinical management controversies arise when these large $\mathrm{HH}$ s are incidentally found ranging from watchful waiting to a number of 
surgical procedures (3). Since the introduction of laparoscopic surgery perioperative complications and hospital stay reduced dramatically (4). On the other hand the magnitude of these operations, the high recurrence rates and the debate among experts for the addition of antireflux procedures or the use of prosthetic material, keeps management of large paraesophageal hernias as a matter of skepticism (5).

The aim of this study is to highlight the usual presentation of patients with large paraesophageal $\mathrm{HHs}$ in everyday clinical practice, the essential baseline workup and investigations needed to assess the $\mathrm{HH}$ and finally, discuss modern, elective and emergent management options.

\section{Materials and Methods}

\section{Hiatus Hernia Classification and Pathophysiology}

The main types of $\mathrm{HH}$ are four, according to the anatomic position of the gastroesophageal junction (GEJ)/gastric cardia (6): a. type I, which is called sliding $\mathrm{HH}$ and is the most common, in which the GEJ/gastric cardia is 'sliding' above the esophageal hiatus orifice and into the chest, b. type II, or true paraesophageal $\mathrm{HH}$, where the gastric fundus is rolling into the mediastinum/chest cavity, while the GEJ/gastric cardia remains normally positioned, c. type III, or mixed type, which combines types I and II, and both the GEJ/ gastric cardia and fundus roll into the chest, and finally $\mathrm{d}$. type IV, where another abdominal organ as the transverse colon is also drawn upward, along the stomach.

Practically, accurate preoperative distinction between these types of $\mathrm{HH}$ is difficult and it is more than often set at surgical exploration. Most authors suggest that large paraesophageal $\mathrm{HH}$ are defined as all $\mathrm{HH}$ including more than a third of the stomach into the chest, regardless of the GEJ/gastric cardia anatomic position (3). The latter includes types II, III and IV of $\mathrm{HHs}$ in a single category that needs similar work-up and management (Fig. 1).

A combination of factors related with advanced age is mostly theorized as the underlying mechanism that led to the development of these large $\mathrm{HHs}$ (7).

Obesity and increased intra-abdominal pressure works similarly to the development of abdominal wall hernias. Age related weakness of the phrenoesophageal membrane, as imbalance of Type 1 and Type 2 collagen, or chronic collagen disorders predispose to HHs. Long-standing gastroesophageal reflux disease (GERD) and the resulting shortened esophagus is another potential co-factor. Also, patients with kyphoscoliosis have increased incidence of large paraesophageal $\mathrm{HHs}_{\mathrm{s}}(8)$.

This review is based on a PubMed literature search using the keywords 'large or giant paraesophageal hernia', 'hiatus or hiatal hernia', 'laparoscopic surgery', 'antireflux surgery', 'mesh', 'gastric volvulus' and 'diaphragmatic hernia' published between 1998 until 2017.

\section{Results}

\section{Clinical Presentation}

Patients with large paraesophageal $\mathrm{HH}$ can be diagnosed incidentally during endoscopic or imaging investigations for unrelated reasons (9).

Despite the above, after careful history taking, most of these patients have been experiencing symptoms even for years, attributing these to other conditions as gastritis, gallstone disease or anxiety and stress. Upper abdominal and chest

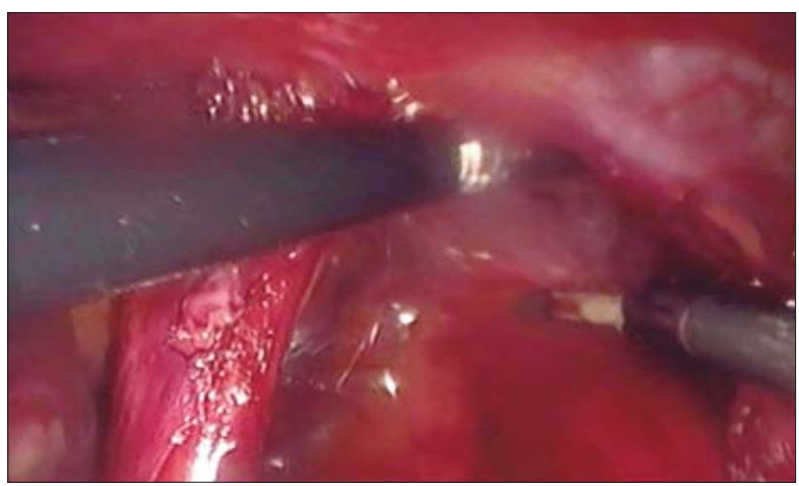

Figure 1. Laparoscopic intraoperative view of the mediastinum /diaphragmatic crus post paraesophageal hiatus hernia reduction 
discomfort as well as heartburn and regurgitation are mostly reported in the presence of these HHs. Folding of the stomach into the hernia sac can apply pressure on the esophagus and cause dysphagia, while patients sometimes have already modified their diet to soft food. The same mechanism and anatomic distortion can cause delayed emptying of the stomach and early satiety, or aggravating reflux like symptoms. Chest pain varies between $9-59 \%$ in relevant studies, and microcytic anemia is also reported in $17-47 \%$ of cases (10). The latter is thought to be caused by 'Cameron's ulcers', which are gastric mucosal erosions from crural pressure applied at the neck of the HH (11). Of course, all other common causes of microcytic anemia should be excluded with upper and lower gastrointestinal endoscopy before attributing anemia to the large paraesophageal HH. Moreover, decreased pulmonary reserve and shortness of breath is a major reason that patients with large $\mathrm{HHs}$ are commonly referred for surgical repair, however only a minor, about $10 \%$, improvement in pulmonary function tests is reported postoperatively (12).

Preoperative symptoms should be thoroughly documented in cases that operative repair is planned, and realistic goals should be set from the surgical intervention.

Acute severe complications are generally rare and include gastric outlet obstruction and strangulation of the stomach, mostly named as 'gastric volvulus'. Ischemic strangulated stomach can lead to perforation and leakage of gastric contents into the mediastinum, which is the main cause of mortality from the presence of large paraesophageal HHs. The clinical presentation of these patients is described with Borchardt's triad: severe epigastric pain, retching with inability to vomit, and failure to place a nasogastric tube, but occurs in $70 \%$ of cases (13). Severe pain of the left upper abdominal quadrant radiating to the left shoulder, may be caused from internal bleeding irritating the diaphragm.

It is very difficult to establish the actual risk of developing the above life-threatening complications, and offer surgery in mostly elderly patients, who have more than often multiple comorbidities. In an interesting study from Stylopoulos et al, a Markov model is used to define the need for elective versus urgent operation when and if needed (14). The outcome of this landmark study was that watchful waiting is the preferred approach for the asymptomatic patients, and elective surgery should be offered to symptomatic patient complaining of gastric outlet obstruction or GERD symptoms.

\section{Work up}

When a large paraesophageal HH is considered in the differential diagnosis a barium swallow test and contrast upper gastrointestinal series can provide the correct diagnosis. Computed tomography (CT) of the chest and upper abdomen is reasonable to be performed to exclude pulmonary disease and define the anatomy of the $\mathrm{HH}$ in more detail. Upper gastrointestinal endoscopy is recommended, but usually this is a lengthy procedure which needs good sedation for the patient and often fails to visualize the distorted anatomically stomach. The endoscope can be coiled into the upside-down stomach and the pylorus or duodenum is sometimes impossible to be assessed. In case of anemia, however, esophagogastroduodenoscopy should be definitely attempted, along with colonoscopy. Caspule enteroscopy is also suggested in the literature to exclude small bowel lesions (15). Routine esophageal physiology tests are not indicated as GERD and increased esophageal intraluminal pressures are demonstrated anyway (16), due to the anatomic distortion and without any underlying functional disorder, thus not adding to the clinician's 'decision making' process.

\section{Management}

The optimal management of large paraoesophageal HHs is still a matter of debate and should be individualized. Gastroenterologists and surgeons are asked to distinguish between asymptomatic and symptomatic patients, since the presence of symptoms is used as the 
principal indication for surgery. It has to be noted though that the vast majority of these patients are in their $70 \mathrm{~s}$ or $80 \mathrm{~s}$, with high prevalence of comorbidities and pose increased operative risk. On the other hand, large $\mathrm{HH}$ repair led to significant quality of life improvement on symptomatic patients regardless of age in previously published studies (17). The surgical approach of choice is laparoscopic surgery, with all the benefits of minimally invasive surgery, and thus an enhanced recovery postoperative course. Sometimes, primary physicians do not refer their elderly patients for surgery due to their poor overall health, but a formal anesthetic risk assessment would be more sensible, before refusing operative repair for symptomatic individuals.

Skepticism exists among clinicians and current literature is of little value towards the optimal management of asymptomatic or minimally symptomatic patients. Estimating the risk of developing the above mentioned severe complications from a large paraesophagel $\mathrm{HH}$ is almost impossible. Even if the number of patients who need emergent operative repair, or acute hospitalization for these conditions can be documented in a retrospectively designed study, the actual denominator of the study sample cannot be calculated. Stylopoulos et al, including five studies results, reported an incidence of acute complications as 0.7 to $7 \%$ per patient per year (14).Mortality rates of acute complications, as gastric volvulus, is reported as high as 16\% (18), so elective surgery is advocated even for minimally symptomatic patients in large population studies (19).

Mortality rates for large paraoesophageal $\mathrm{HH}$ repair are very low, less than $1 \%$, in the elective setting $(20,21)$ (Table 1). These rates and significant postoperative morbidity were higher in the open surgery era, however nowadays, laparoscopic approach is the norm even for emergency surgical repair (22). A recent review on the subject, concludes that elective surgery should be offered in all symptomatic patients unless they have very high anaesthetic risk regardless of their age, and to all asymptomatic or minimally symptomatic patients up to the age of 75 (1). The latter is justified from the mortality rate that emergent repair poses. Another very interesting study, claimed that "non-elective repair was independently associated with 1.7 times increased odds of major adverse events and trended toward an increase of 2.7 times for odds of mortality compared to elective repair, after accounting for age and comorbid index score (23). Emergency repair of a large paraesophageal $\mathrm{HH}$ is associated with increased morbidity in comparison with elective surgery, in a study of the American College of Surgeons National Surgical Quality Improvement Program, including 383 patients (16\% versus 1.6\%) (22).

Acute presentation with incarcerated stomach into the chest, due to gastric volvulus, should be managed with resuscitation of the patient and an initial effort to decompress the stomach (24). A gentle nasogastric tube placement or even urgent upper gastrointestinal endoscopy and aspiration can be very helpful, and if successful it gives the patient enough time to be transferred to the appropriate surgical unit for a semi-urgent operation under improved conditions. If the above maneuvers fail, then emergency surgical decompression, and repair of the large paraesophageal HH is indicated.

Table 1. Postoperative complications of laparoscopic large paraesophageal hiatus hernia repair in the elective versus emergent setting

\begin{tabular}{lcccc}
\hline Authors & Year & $\begin{array}{c}\text { Number of pts } \\
\text { Elective/Emergent }\end{array}$ & $\begin{array}{c}\text { Morbidity } \\
\text { Elective/Emergent }\end{array}$ & $\begin{array}{c}\text { Mortality } \\
\text { Elective/Emergent }\end{array}$ \\
\hline Tam et al (23) & 2016 & $753 / 171$ & $18 \% / 38 \%$ & $1 \% / 8 \%$ \\
\hline Kaplan et al (22) & 2015 & $10273 / 383$ & $5.2 \% / 21 \%$ & $0.65 \% / 5.5 \%$ \\
\hline Jassim et al (19) & 2014 & $30958 / 10765$ & $16.5 \% / 33.4 \%$ & $0.37 \% / 3.2 \%$ \\
\hline Polomsky et al (37) & 2010 & $104 / 23$ & $3 \% / 30 \%$ & $1 \% / 22 \%$ \\
\hline
\end{tabular}




\section{Discussion}

Large paraesophageal $\mathrm{HHs}$ are increasingly found in an ageing population, who undergoes more and more tomographic imaging studies for unrelated reasons. Primary physicians and eventually gastroenterologists and surgeons are confronted with the optimal management queries on the matter. Controversies exist in every aspect, starting from the troublesome definition of the condition, the actual symptoms, the optimal diagnostic work-up, management options and finally surgical techniques and long-term outcomes.

In regards with the optimal surgical approach, laparoscopic surgery is the mainstay of treatment approaches, benefiting patients from reduced postoperative pain, shorter hospital stay, less surgical trauma complications. Early reports of increased recurrence rates of laparoscopic repair in comparison to the open approach, attributed to less adhesions intraabdominally after laparoscopy, are counterfeited as laparoscopic repair is standardized (25). Laparoscopy is the preferred route in both elective and emergency repair, with a higher though risk of conversion to open in the latter setting $(26,27)$.

In terms of surgical considerations and controversies, it is widely accepted that the hernia sac should be 'non-aggressively' resected, to avoid excessive bleeding or truncal vagus nerve injuries (28). The hiatal defect should be closed and the use of prosthetic mesh is a matter of debate among upper gastrointestinal surgeons. A meta-analysis (29) and a recent review (30) have discordant results and in practice the use of prosthetic material around the esophagus varies according to the individual surgeon's preferences. Characteristically in a study from the Society of American Gastrointestinal and Endoscopic Surgeons (SAGES), 23\% of surgeons never used a mesh on principle around the gastroesophageal junction and $25 \%$ almost always use prosthetic material to reinforce the hiatus (6). The actual material used is also important, as nonabsorbable polypropylene mesh can erode the esophagus even many years later, which can have devastating consequences (31). On the other hand, if absorbable polytetrafluoroethylene (PTFE) type of mesh is used, then recurrence rates are higher (32). Lengthening of the esophagus with a 'Collis gastroplasty' is rarely if ever needed since laparoscopic mobilization of the esophagus is very effective, reaching high into the mediastinum, achieving almost always a good intraabdominal esophageal length. Nevertheless, quality of life is very good in the rare event of such a procedure needed intraoperatively (33). A partial of even full 3600 fundoplication is an essential part of the operation reducing the recurrence rates and treating the underlying GERD which practically co-exist in most patients, without significant postoperative dysphagia and bloating (27).

Another issue that a clinician may come across is the recurrent hiatus hernia after initial surgical repair. The rates reported after laparoscopic or open large paraesophageal $\mathrm{HH}$ repair are very high, up to $60 \%$ (34), if strict radiological and anatomical criteria are used. In reality though, clinically most of the patients having anatomical recurrence of a $\mathrm{HH}$ remain asymptomatic with good quality of life, which has definitely improved after surgery (35). In the light of the above, follow up upper gastrointestinal series or CT scans suggesting recurrent $\mathrm{HHs}$ should be interpreted carefully taking into account the patient's complains and symptoms. Reopera-tions have a high morbidity rate and should be performed after excessive preoperative investigations in high volume centers, and after having frank consultation with the patient regarding potential complications and suboptimal long-term results (36).

\section{Conclusion}

In conclusion, more studies are needed to address the unanswered questions regarding the optimal management of large paraesophageal HHs. Elective surgery should be offered to all symptomatic patients and to asymptomatic individuals of low operative risk. Meticulous preoperative evaluation of the operative risks and a pragmatic discussion 
with the patient and his family for the potential risks and benefits are of paramount importance. The laparoscopic approach is established and the use of prosthetic mesh is still under debate. Recurrence rates are high, however symptomatic recurrence is rare.

\section{Declaration of interest}

The authors report no conflicts of interest. The authors alone are responsible for the content and writing of the paper.

\section{Conflicts of Interest and Source of Funding}

All authors declare no conflict of interest nor any funding regarding the publication of this study.

\section{References}

1. Collet D, Luc G, Chiche L. Management of large para-esophageal hiatal hernias. J Visc Surg. 2013;150(6):395-402.

2. Sihvo El, Salo JA, Räsänen JV, Rantanen TK. Fatal complications of adult paraesophageal hernia: a population-based study. J Thorac Cardiovasc Surg. 2009;137(2):419-24.

3. Mitiek MO, Andrade RS. Giant hiatal hernia. Ann Thorac Surg. 2010;89(6):S2168-73

4. Draaisma WA, Gooszen HG, Tournoij E, Broeders IA. Controversies in paraesophageal hernia repair: a review of literature. Surg Endosc. 2005;19(10):1300-8. Epub 2005 Aug 4.

5. Duranceau A. Massive hiatal hernia: a review. Dis Esophagus. 2016:29(4):350-66.

6. Pfluke JM, Parker M, Bowers SP, Asbun HJ, Daniel Smith C.Use of mesh for hiatal hernia repair: a survey of SAGES members. Surg Endosc. 2012;26(7):1843-8.

7. Menon S, Trudgill N. Risk factors in the aetiology of hiatus hernia: a metaanalysis. Eur J Gastroenterol Hepatol. 2011;23(2):133-8.

8. Schuchert MJ, Adusumilli PS, Cook CC, Colovos C, Kilic A, Nason KS, et al. The impact of scoliosis among patients with giant paraesophageal hernia. J Gastrointest Surg. 2011;15(1):23-8.

9. Oelschlager BK, Petersen RP, Brunt LM, Soper NJ, Sheppard BC, Mitsumori L, et al. Laparoscopic paraesophageal hernia repair: defining long-term clinical and anatomic outcomes. J Gastrointest Surg. 2012;16(3):453-9.

10. Carrott PW1, Hong J, Kuppusamy M, Koehler RP, Low DE. Clinical ramifications of giant paraesophageal hernias are underappreciated: making the case for routine surgical repair. Ann Thorac Surg. 2012; 94(2):421-6; discussion 426-8.

11. Carrott PW, Markar SR, Hong J, Kuppusamy MK, Koehler RP, Low DE. Iron-deficiency anemia is a common presenting issue with giant paraesophageal hernia and resolves following repair. J Gastrointest Surg. 2013;17(5):858-62.

12. Carrott PW, Hong J, Kuppusamy M, Kirtland S, Koehler RP, Low DE. Repair of giant paraesophageal hernias routinely produces improvement in respiratory function. J Thorac Cardiovasc Surg. 2012:143(2):398-404.

13. Cardile AP, Heppner DS. Gastric volvulus, Borchardt's Triad, and Endoscopy: A Rare Twist. Hawaii Med J. 2011;70(4):80-2.

14. Stylopoulos N1, Gazelle GS, Rattner DW. Paraesophageal hernias: operation or observation? Ann Surg. 2002;236(4):492-500; 15. Haurani C, Carlin AM, Hammoud ZT, Velanovich V. Prevalence and resolution of anemia with paraesophageal hernia repair. J Gastrointest Surg. 2012;16(10):1817-20. Epub 2012 Jul 28.

16. Lebenthal A, Waterford SD, Fisichella PM. Treatment and controver- sies in paraesophageal hernia repair. Front Surg 2015;2:13.

17. Mori T1, Nagao G, Sugiyama M. Paraesophageal hernia repair. Ann Thorac Cardiovasc Surg. 2012;18(4):297-305.

18. Poulose BK, Gosen C, Marks JM, Khaitan L, Rosen MJ, Onders RP, et al. Inpatient mortality analysis of paraesophageal hernia repair in octogenarians. J Gastrointest Surg. 2008;12(11):1888-92.

19. Jassim H, Seligman JT, Frelich M, Goldblatt M, Kastenmeier A, Wallace $J$, et al. A population-based analysis of emergent versus elective paraesophageal hernia repair using the Nationwide Inpatient Sample. Surg Endosc. 2014;28(12):3473-8.

20. Luketich JD, Nason KS, Christie NA, Pennathur A, Jobe BA, Landreneau RJ, et al. Outcomes after a decade of laparoscopic giant paraesophageal hernia repair. J Thorac Cardiovasc Surg. 2010;139(2):395-404, 404.e1.

21. Larusson HJ, Zingg U, Hahnloser D, Delport K, Seifert B, Oertli D. Predictive factors for morbidity and mortality in patients undergoing laparoscopic paraesophageal hernia repair: age, ASA score and operation type influence morbidity. World J Surg. 2009:33(5):980-5.

22. Kaplan JA, Schecter S, Lin MY, Rogers SJ, Carter JT. Morbidity and Mortality Associated With Elective or Emergency Paraesophageal Hernia Repair. JAMA Surg. 2015;150(11):1094-6.

23. Tam V, Luketich JD, Winger DG, Sarkaria IS, Levy RM, Christie NA, et al. Non-Elective Paraesophageal Hernia Repair Portends Worse Outcomes in Comparable Patients: a Propensity-Adjusted Analysis. J Gastrointest Surg. 2017;21(1):137-145.

24. Bawahab M, Mitchell P, Church N, Debru E. Management of acute paraesophageal hernia. Surg Endosc. 2009;23(2):255-9.

25. Zehetner J, Demeester SR, Ayazi S, Kilday P, Augustin F, Hagen JA, et al. Laparoscopic versus open repair of paraesophageal hernia: the second decade. J Am Coll Surg. 2011;212(5):813-20.

26. Li J, Rosenthal RJ, Roy M, Szomstein S, Sesto M. Experience of laparoscopic paraesophageal hernia repair at a single institution. Am J Surg. 2012;204(1):60-5.

27. Klinginsmith M, Jolley J, Lomelin D, Krause C, Heiden J, Oleynikov D. Paraesophageal hernia repair in the emergency setting: is laparoscopy with the addition of a fundoplication the new gold standard? Surg Endosc. 2016:30(5):1790-5.

28. Edye M, Salky B, Posner A, Fierer A. Sac excision is essential to adequate laparoscopic repair of paraesophageal hernia. Surg Endosc. 1998:12(10):1259-63.

29. Antoniou SA, Antoniou GA, Koch 00, Pointner R, Granderath FA. Lower recurrence rates after mesh-reinforced versus simple hiatal hernia repair: a meta-analysis of randomized trials. Surg Laparosc Endosc Percutan Tech. 2012;22(6):498-502.

30. Obeid NM, Velanovich V. The choice of primary repair or mesh repair for paraesophageal hernia: a decision analysis based on utility scores. Ann Surg. 2013;257(4):655-64.

31. Frantzides CT, Carlson MA, Loizides S, Papafili A, Luu M, Roberts J, et al. Hiatal hernia repair with mesh: a survey of SAGES members. Surg Endosc. 2010; 24(5):1017-24.

32. Chilintseva N, Brigand C, Meyer C, Rohr S. Laparoscopic prosthetic hiatal reinforcement for large hiatal hernia repair. J Visc Surg. 2012; 149(3):e215-20.

33. Alicuben ET, Worrell SG, DeMeester SR. Impact of crural relaxing incisions, Collis gastroplasty, and non-cross-linked human dermal mesh crural reinforcement on early hiatal hernia recurrence rates. J Am Coll Surg. 2014;219(5):988-92.

34. Dallemagne B, Kohnen L, Perretta S, Weerts J, Markiewicz S, Jehaes C. Laparoscopic repair of paraesophageal hernia. Long-term follow-up reveals good clinical outcome despite high radiological recurrence rate. Ann Surg. 2011;253(2):291-6.

35. Furnée EJ, Draaisma WA, Simmermacher RK, Stapper G, Broeders IA. Long-term symptomatic outcome and radiologic assessment of laparoscopic hiatal hernia repair. Am J Surg. 2010; 199(5):695-701.

36. Targarona EM, Grisales S, Uyanik O, Balague C, Pernas JC, Trias M. Long-term outcome and quality of life after laparoscopic treatment of large paraesophageal hernia. World J Surg. 2013:37(8): 1878-82.

37. Polomsky M, Hu R, Sepesi B, O'Connor M, Qui X, Raymond DP, et al. A population-based analysis of emergent vs. elective hospital admissions for an intrathoracic stomach. Surg Endosc. 2010; 24(6):1250-5. 